\title{
ESTIMATION OF FLEXIBLE PAVEMENT BY USING STABILIZED SOIL WITH STEEL SLAG AND BITUMEN EMULSION
}

\author{
Sujit Murlidhar Vaijwade \\ PG Student, Department of Civil Engineering \\ Government Engineering College, \\ Aurangabad, Maharashtra, India
}

\begin{abstract}
The main objective of this experimental study is to improve the properties of the expansive soil by adding steel slag, Bitumen Emulsion. An attempt has been made to use steel slag, Bitumen Emulsion for improving the strength of expansive soil expressed in terms of CBR values, which may prove to be economical. In this study, the whole laboratory work revolves around the basic properties of soil and its strength in terms of CBR. It is observe that excellent soil strength results by using steel slag (SS) as well as Bitumen Emulsion (BE). In a project the strength of soil is increase by adding steel slag, bitumen and both steel slag and Bitumen Emulsion instead of replacing with stronger soil. The initial strength of the soil is determined by conducting soil tests such as specific gravity, plastic limit, liquid limit, standard proctor compaction test, unconfined compressive strength and California bearing ratio tests. The steel slag used in two sizes less than $4.75 \mathrm{~mm}$ and size between $4.75 \mathrm{~mm}$ to $10 \mathrm{~mm}$ which is known as Steel Slag type $A$ and $B$. The results obtained are then compare with the soil treated with 5\%, $10 \%, 15 \%, 20 \%$ and $25 \%$ of steel slag. In addition, the results obtained are then compare with the soil treated with $\mathbf{2 . 5 \%}, \mathbf{5 \%}, \mathbf{7 . 5 \%}, \mathbf{1 0 \%}$, and $12.5 \%$ of Bitumen Emulsion. Further the optimum percentage of steel slag of both types and Bitumen Emulsion is mixed with soil together with different combination.
\end{abstract}

Keywords - Expansive Soil, CBR, Steel slag, Bitumen Emulsion, standard proctor compaction test, unconfined compressive strength

\section{INTRODUCTION}

Nearly 51.8 million hectares of land area in India are cover with Expansive soil (mainly Black Cotton soil). The property of these expansive soils, in general, is that they are very hard when in dry state, but they lose all of their strength when in wet state. In light of this property of expansive soils, these soils pose problems worldwide that serve as challenge to overcome for the Geotechnical engineers. Starting from the base, soil is a standout amongst the most abundant

\author{
Dr. Shubhada S. Koranne \\ Associate Professor, Department of Civil Engineering \\ Government Engineering College, \\ Aurangabad, Maharashtra, India
}

construction materials of nature. Just about all kind of construction is based with or upon the soil. Long-term performance of pavement structures is altogether affected by the strength and durability of the subgrade soils.

Partial replacement of expansive soil by bitumen emulsion and steel slag is the solution for problems mentioned above. In this research work, expansive soil is replaced with bitumen emulsion $2.5 \%, 5 \%, 7.5 \%, 10 \%, 12.5 \%$, and steel slag at $5 \%, 10 \%, 15 \%, 20 \%, 25 \%$ and $30 \%$. Then finally, both bitumen emulsion and steel slag were use together with optimum percentage. All the key geo-technical tests like plastic limit, liquid limit, standard proctor and California bearing tests and unconfined compressive strength were conducted as per IS codes. The results of soil at different replacement percentages were compare to conclude the overall optimum percentage of that particular material in expansive soil.

\section{Literature Review}

Shubham Langar et al. (2018) ${ }^{\mathbf{1}}$ studied on Enhancement of Shear Strength of Soil Using Bitumen, in this study he disused that to improve the properties of the gravely soil by adding bitumen emulsion as stabilizing agent and little bit cement as filler.

Olumide Moses Ogundipe (2014) ${ }^{2}$ had proposed about strength and compaction characteristics of bitumen-stabilized granular soil. In his study, he has discussed about the investigation of the stabilization of granular soil with bitumen. R. Deby Linsha et al. (2016) ${ }^{3}$ proposed about performance evaluation of improvement of shear strength of soil using bitumen emulsion the strength of soil is increased by adding bituminous emulsion instead of replacing with stronger soil.

Paul et al. (2011) ${ }^{4}$ suggested an introduction to soil stabilization in pavement taking a mixture of bitumen and well-graded gravel or crushed aggregate. After compaction, it gave an exceedingly steady waterproof mass of sub base or base course quality.

Martin et al. (2009) ${ }^{\mathbf{5}}$ developed a paper deals with foam bitumen stabilization. Foamed bitumen is a mixture of bitumen, air and water.

Yuehuan et al. (2010) ${ }^{6}$ Heworked on foamed bitumen stabilization for Western Australian pavements. Currently, the 


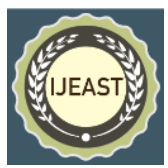

popularity of soil cement stabilization has been challenge by a new innovative soil improvement technique, known as foamed bitumen stabilization.

Satyendra kumar verma $\mathbf{( 2 0 1 5}^{7}$ directed a test research on a laboratory study on use of bitumen emulsion in black soil. The whole laboratory work revolves around the basic properties of soil and its strength in terms of CBR. $\mathbf{V}$.

Shashank, et al (2017) ${ }^{\mathbf{8}}$ studied on application of steel slag as an effective construction material in pavements. He has found that, the powdered steel slag acts as a good binding material in the pavements.

Chippada Srinivas (2017) ${ }^{\mathbf{9}}$ carried out an excellent work to establish the experimental investigation on expansive soil stabilization by using steel slag. He conclude that Steel slag is a by product of steel manufacturing industry which is dumped in large quantities every year.

Saurabh Kumar et al. (2016) $)^{\mathbf{1 0}}$ concentrated on the stabilization of clayey soil using steel slag. In his project, strength characteristics of clayey soil with steel slag has been studied.

Dr. B. M. Patil (2018) ${ }^{11}$ directed a test research on effect of steel slag on CBR value of black cotton soil. The evaluate effect of addition of steel slag with various percentages to stabilize the black cotton soil and to verify its suitability to be used as a construction material for road, embankment and structural fills.

\section{PROPOSED METHODOLOGY}

\section{Sample Collection}

1.1 Black Cotton Soil The black cotton soil used in the present study is locally available soil taken from near Everrest Engineering College, Jatwada Road, Aurangabad. The materials were excavating from $1 \mathrm{~m}$ below the ground surface. Soil is the principal material for the construction of embankment and subgrade of highways. The design and performance of the pavement, particularly the flexible pavement, depends on the type of subgrade soil and its properties. Some of the essential laboratory tests were carried out to determine the engineering properties i.e. index properties, atterbarge limits and strength characteristicsof the soils. Laboratory tests were carried out as per relevant IS codes.

\subsection{Steel Slag}

Steel slag, a by-product of steel making, is produce during the separation of the molten steel from impurities in steel-making furnaces. The slag occurs as a molten liquid melt and is a complex solution of silicates and oxides that solidifies upon cooling. Virtually all steel is now made in integrated steel plants using a version of the basic oxygen process or in specialty; steel plants (mini-mills) are using an electric arc furnace process. The open-hearth furnace process is no longer used.Steel slag can normally be obtained from slag processors who collect the slag from steel-making facilities. Slag processors may handle a variety of materials such as steel slag, ladle slag, pit slag, and used refractory material to recover steel metallics. These materials must be source separated, and well-defined handling practices must be in place to avoid contamination of the steel slag aggregate. The slag processor must also be aware of the general aggregate requirements of the end user. Steel slag aggregates are highly angular in shape and have rough surface texture. They have high bulk specific gravity and moderate water absorption (less than 3 percent).

Table 1 Typical Physical Properties of Steel Slag.

\begin{tabular}{|c|c|c|}
\hline Sr. No. & Property & Value \\
\hline 1 & Specific Gravity & 2.34 \\
\hline 2 & Unit Weight $(\mathrm{gm} / \mathrm{cc})$ & 1.60 to 1.92 \\
\hline 3 & Water Absorption & up to $3 \%$ \\
\hline
\end{tabular}

In present project work, the steel slag is use in two types according to their size. First type is steel stag which is passing through $4.75 \mathrm{~mm}$ IS sieve which is known as Steel Slag Type A. The second type is Steel slag which is passing through 10 $\mathrm{mm}$ IS sieve and retained on $4.75 \mathrm{~mm}$ IS sieve which is known as Steel slag Type B. The steel slag is use for experiment in 5\%,10\%,15\%, 20\%, etc. with soil.

\subsection{Bitumen Emulsion}

Bitumen emulsion is a mixture of fine droplets of bitumen and water. However, as the bitumen is a petroleum product it does not mix with water and as it is sticky in nature, it does not easily gets disintegrated into fine droplets. To overcome this problem an emulsifier is used. Emulsifier can be defined as a surface-active agent. Emulsifier keeps the bitumen in its fine droplet state by disallowing it to mix with other droplets. As the droplets are very fine they suspend in water. In this present study, the thinner is used as emulsifier and slow setting bitumen emulsion (SS-2) is used. It is having low viscosity and extended setting time that makes it a perfect product for road maintenance applications. It is chocolate brown in color and is a free flowing liquid at ambient temperature. Our SS-2 is manufactured strictly as per IS 8887:2004

The main advantages of slow setting emulsion (SS-2) is No heating require, cost efficient, damp surfaces, Low temperature curing, high adhesive properties, Penetrate the cracks and services and impart, strength to the layers, Environment friendly. The bitumen emulsion is used for experiment in $2.5 \%, 5 \%, 7.5 \%, 10 \%$, etc. with soil.
2. Experimental Work
2.1 Specific Gravity Test
2.2 Particle Size Distribution
2.3 Liquid Limit
2.4 Plastic Limit
2.5 Standard Proctor Test
2.6 CBR Test (California Bearing Ratio Test)
2.7 Unconfined Compression Test 


\section{International Journal of Engineering Applied Sciences and Technology, 2020 Vol. 4, Issue 11, ISSN No. 2455-2143, Pages 282-288 \\ Published Online March 2020 in IJEAST (http://www.ijeast.com)}

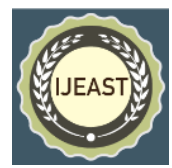

2.8 Flexible Pavement Design as per IRC-37-2001 Traffic Count Survey

The Calculation of vehicles is done with the traffic data and axle load survey as per IRC 37:2001. The design procedure given by IRC makes use of the CBR value, million standard axle concept, and vehicle damage factor. Traffic distribution along the lanes is taken into account. The design is meant for design traffic which is arrived at using a growth rate. Flexible pavements are considered to include the pavements which have bituminous surfacing and granular base and sub-base courses conforming to IRC/ MOST standards. These guidelines apply to new pavements.

\subsubsection{Design Traffic}

The design traffic is considered in terms of cumulative number of standard axles (in the lane carrying maximum traffic) to be carried during the design life of pavement using

$$
\left.\mathbf{N}=\left\{365 \times\left[(1+r)^{\wedge} \mathbf{n}-1\right] / \mathbf{r}\right\} \times\{\mathbf{A} \times \mathbf{D} \times \mathbf{F})\right\}
$$

The cumulative number of standard axles to be catered for in the design life in terms of msa

$\mathrm{A}=$ Initial traffic in the year of completion of construction in terms of the number of commercial vehicles per day

$\mathrm{D}=$ Lane distribution factor

$\mathrm{F}=$ Vehicle damage factor

$\mathrm{n}=$ Design life in years

$r=$ Annual growth rate of commercial vehicles

The traffic in the year of completion is estimate using

$\mathbf{A}=\mathbf{P}(\mathbf{1}+\mathbf{r})^{\wedge} \mathbf{x}$

$\mathrm{P}=$ Number of commercial vehicles as per last count

$\mathrm{x}=$ Number of years between the last count and the year of completion of construction.

\subsubsection{Traffic growth rate}

Traffic growth rates should be estimated by studying the past trends of traffic growth, and by establishing econometric models, as per the procedure outlined in IRC:108"Guidelines for traffic prediction on rural highways". If adequate data is not available, it is recommended that an average annual growth rate of 7.5 percent may be adopted.

\subsubsection{Design Life}

For the design of pavement, the design life is defined in terms of the cumulative number of standard axles that can be carried before strengthening of pavement is necessary.

It is recommended that pavements for National Highways $(\mathrm{NH})$ and State Highways (SH)should be design for a life of 15 years. Expressways and Urban roads nay be designed for a longer life of 20 years. For other categories of roads, a design life of 10 to 15 years may be adopted.

\subsection{Vehicle Damage Factor}

Sufficient information on axle loads is not available and project does not warrant conducting an axle load survey, the indicative values of vehicle damage factor as given below may be used.

\subsubsection{Design Charts and Catalogue}

Based on the performance of existing designs and using analytical approach, simple design charts (Figure 2.13 and
2.14) and a catalogue of pavement designs are added in the code. The pavement designs are given for subgrade CBR values ranging from $2 \%$ to $10 \%$ and design traffic ranging from $1 \mathrm{msa}$ to $150 \mathrm{msa}$ for an average annual pavement temperature of $35 \mathrm{C}$. The later thicknesses obtained from the analysis have been slightly modified to adapt the designs to stage construction. Using the following simple input parameters, appropriate designs could be chosen for the given traffic and soil strength

- Design traffic in terms of cumulative number of standard axles; and

- CBR value of subgrade.

The designs relate to ten levels of design traffic $1,2,3,4,5$, 10, 20, 30, 50, 100 and $150 \mathrm{msa}$. For intermediate traffic ranges, the pavement layer thickness may be interpolated linearly. For traffic exceeding $150 \mathrm{msa}$, the pavement design appropriate to $150 \mathrm{msa}$ may be chosen and further strengthening carried out to extend the life at appropriate time based on pavement deflection measurements as per IRC : 81 . Available Data:

1. Design of CBR of Subgrade Soil : $2 \%$

2. Design Life of Pavement (n): 15 years

3. Annual Growth rate (r): $7.5 \%$

4. Distribution of Commercial vehicle for Single Lane (D): 0.75 (Double Lane).

\subsection{Estimation of road}

The unit cost of road construction in dollars per kilometer is the sum of the subunit costs of the road construction activities. Road construction unit costs are estimated by dividing the machine rates by the production rates for the various activities involved in road construction. The road construction activities considered here are surveying, clearing and grubbing, excavation, surfacing, and drainage.

Flexible Pavements are constructed from bituminous or unbound material and the stress is transmitted to the sub-grade through the lateral distribution of the applied load with depth. Here the estimation of flexible pavement is calculated. The typical cross section of flexible pavement is as shown below. The estimation of flexible pavement is calculated by considering the normal soil and stabilized soil. The thickness of different layers are considered as per given in table No. 62 . For estimation of flexible pavement, the following parameters are considered.

1. The surface of earth under construction is plane i.e. no cutting and filling is required or cutting and filling is already done.

2. The depth of black cotton soil is up to $200 \mathrm{~mm}$. hence the depth of excavation is $200 \mathrm{~mm}$.

3. The pavement is considered as single lane, therefore the width of carriage way is $3.75 \mathrm{~m}$ and the width at subgrade is $4.75 \mathrm{~m}$.

4. The length of pavement is $1 \mathrm{~km}$ and thickness of each layer is considered as per stabilized material is used in table given 


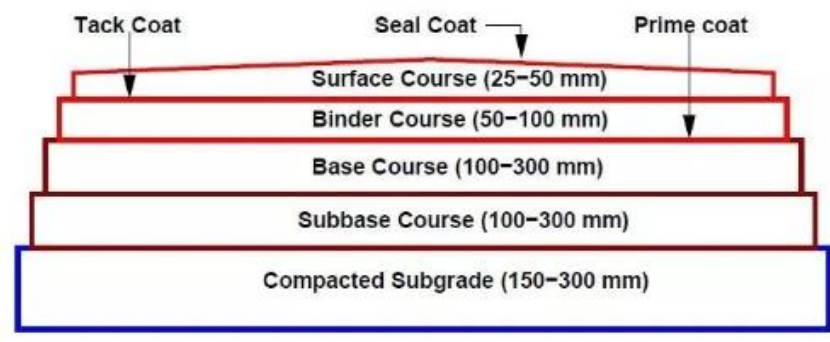

Natural Subgrade

Fig. 1 Typical Cross Section of Flexible Pavement

\section{EXPERIMENT AND RESULT}

The various geotechnical properties of the procured soil are as follows:

Table 2 Properties of Soil

\begin{tabular}{|c|c|c|}
\hline $\begin{array}{c}\text { Sr. } \\
\text { No. }\end{array}$ & Properties & Value \\
\hline 1 & Specific Gravity & 2.42 \\
\hline 2 & Maximum Dry Density (MDD) & $1.5 \mathrm{gm} / \mathrm{cc}$ \\
\hline 3 & Optimum Moisture Content (OMC) & $18.82 \%$ \\
\hline 4 & Liquid Limit (LL) & $48 \%$ \\
\hline 5 & Plastic Limit (PL) & $25.64 \%$ \\
\hline 6 & Plasticity Index (Ip) & 22.36 \\
\hline 7 & CBR (UnSoak) & 3.85 \\
\hline 8 & CBR (Soak) & 1.85 \\
\hline 9 & Unconfined Compressive Strength & $1.052 \mathrm{Kg} / \mathrm{cm}^{2}$ \\
\hline 10 & IS Classification & $\begin{array}{c}\text { Inorganic clay } \\
\text { soil }\end{array}$ \\
\hline
\end{tabular}

\section{Standard Proctor Test}

The standard proctor test is carried out on soil, soil and steel slag type $\mathrm{A}(\mathrm{SSA})$ i.e. steel slag passing through $4.75 \mathrm{~mm}$ IS sieve, soil and Steel Slag type B (SSB) i.e. steel slag passing through $10 \mathrm{~mm}$ IS sieve and retained on $4.75 \mathrm{~mm}$ Is Sieve, Bitumen Emulsion (BE).

The following table shows the optimum percentage of steel slag and bitumen emulsion for maximum dry density and optimum moisture content.

Table 3 MDD and OMC of Soil with Materials

\begin{tabular}{|c|c|c|c|}
\hline $\begin{array}{c}\text { Sr. } \\
\text { No. }\end{array}$ & Material & $\begin{array}{c}\text { MDD } \\
(\mathbf{g m} / \mathbf{c c})\end{array}$ & $\begin{array}{c}\text { OMC } \\
(\mathbf{\%})\end{array}$ \\
\hline 1 & Soil & 1.50 & 18.82 \\
\hline 2 & Soil+ 20\% Steel Slag Type A & 1.79 & 18.48 \\
\hline 3 & Soil+ 25\% Steel Slag Type B & 1.93 & 17.29 \\
\hline 4 & Soil+ 10\%Bitumen Emulsion & 1.92 & 15.15 \\
\hline 5 & $\begin{array}{c}\text { Soil+ 20\% Steel Slag Type A } \\
+10 \% \text { Bitumen Emulsion }\end{array}$ & 2.05 & 14.00 \\
\hline 6 & $\begin{array}{c}\text { Soil+ 25\% Steel Slag Type B } \\
+10 \% \text { Bitumen Emulsion }\end{array}$ & 2.14 & 13.77 \\
\hline
\end{tabular}

Following graph shows the variation of maximum dry density (MDD) of soil with the optimum percentage of steel slag and bitumen emulsion and also combination of both.

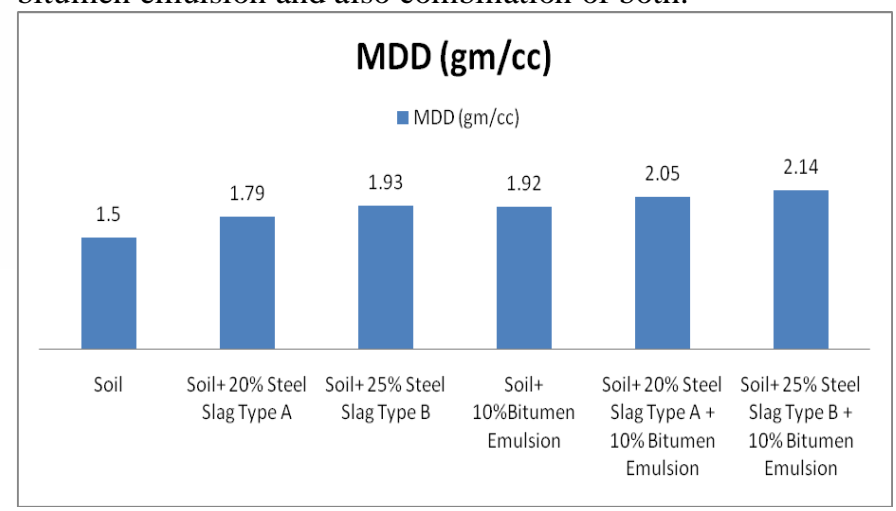

Graph 1 Maximum Dry Density of Soil with Materials

Following graph shows the variation of optimum moisture content (OMC) of soil with the optimum percentage of steel slag and bitumen emulsion for maximum dry density and combination of both.

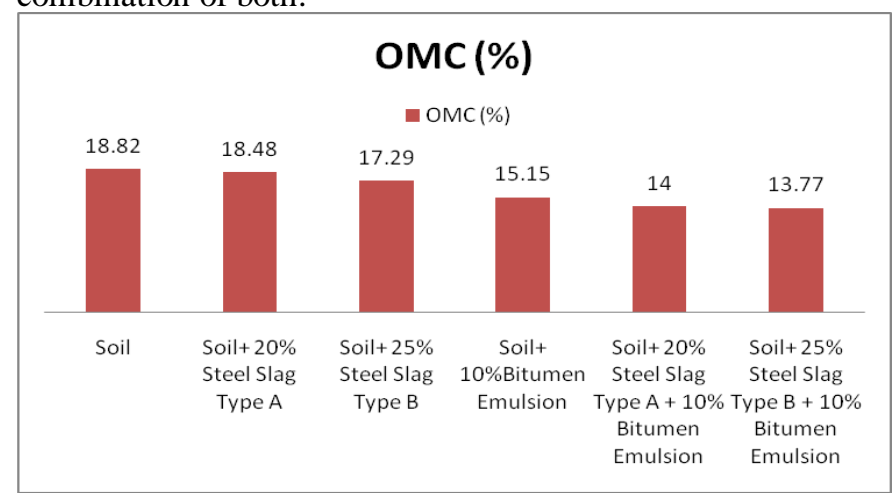

Graph 2 Optimum Moisture Content of Soil with Materials

\section{CBR Test (California Bearing Ratio Test)}

The CBR values at $2.5 \mathrm{~mm}$ and $5.0 \mathrm{~mm}$ penetrations are calculated for each specimen from the corresponding graphs, which is shown below. Generally, the CBR value at $2.5 \mathrm{~mm}$ penetration is higher and this value is adopted. Here testing is done on with different percentage of steel slag of type A, steel slag of B, Bitumen Emulsion and combination of both material in Unsoak and soak Condition.

The following table shows the optimum percentage of steel slag and bitumen emulsion for CBR value in un-soak and soak Condition.

Table 4 CBR Value of Soil with Materials

\begin{tabular}{|c|c|c|c|}
\hline $\begin{array}{c}\text { Sr. } \\
\text { No. }\end{array}$ & Material & $\begin{array}{c}\text { CBR(\%) } \\
\text { (Un-soak) }\end{array}$ & $\begin{array}{c}\text { CBR(\%) } \\
\text { (Soak) }\end{array}$ \\
\hline 1 & Soil & 3.85 & 1.85 \\
\hline 2 & Soil+ 20\% Steel Slag Type A & 7.85 & 3.70 \\
\hline 3 & Soil+ 25\% Steel Slag Type B & 8.62 & 4.16 \\
\hline
\end{tabular}




\begin{tabular}{|c|c|c|c|}
\hline 4 & Soil+ 10\%Bitumen Emulsion & 7.70 & 3.85 \\
\hline 5 & $\begin{array}{c}\text { Soil+ 20\% Steel Slag Type A } \\
+10 \% \text { Bitumen Emulsion }\end{array}$ & 9.24 & 4.93 \\
\hline 6 & $\begin{array}{c}\text { Soil+ 25\% Steel Slag Type B } \\
+10 \% \text { Bitumen Emulsion }\end{array}$ & 10.17 & 6.01 \\
\hline
\end{tabular}

Following graph shows the variation of CBR value in un-soak and Soak Condition of soil with the optimum percentage of steel slag and bitumen emulsion also combination of both.

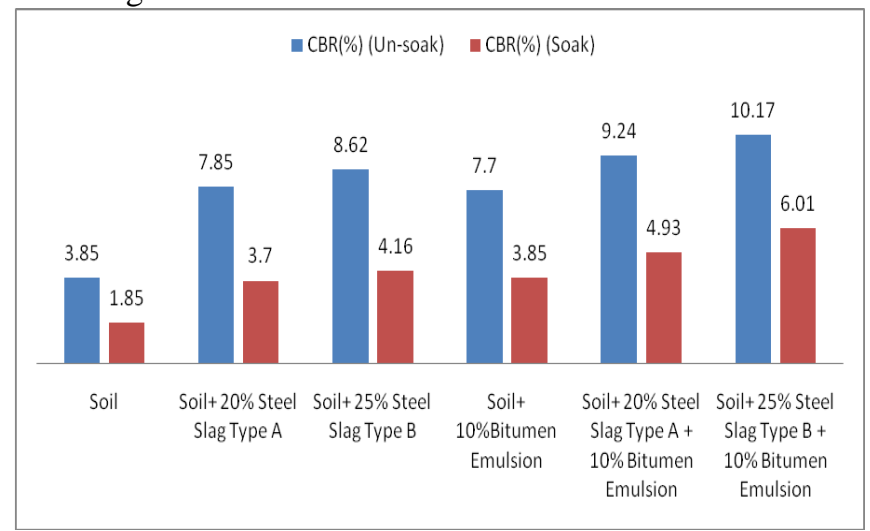

Graph 3 CBR Value of Soil with Materials

\section{Unconfined Compressive Strength}

The compressive strength of original soil first calculated. With varying percentage of steel slag Type A, bitumen emulsion mix with soil the compressive strength of soil is calculated. After finding optimum percentage of both steel slag and bitumen emulsion different combination of both is used for calculation of unconfined compressive strength of soil.

The unconfined compressive strength of soil is determined by using steel slag type a, bitumen emulsion. Also find determine the effect of steel slag and bitumen emulsion together on soil

Table 5 Unconfined Compressive Strength of Soil with Materials

\begin{tabular}{|c|c|c|}
\hline $\begin{array}{c}\text { Sr. } \\
\text { No. }\end{array}$ & Material & $\begin{array}{c}\mathbf{U C S} \\
\left(\mathbf{k g} / \mathbf{c m}^{2}\right)\end{array}$ \\
\hline 1 & Soil & 1.052 \\
\hline 2 & Soil+ 20\% Steel Slag Type A & 1.661 \\
\hline 3 & Soil+ 10\%Bitumen Emulsion & 1.514 \\
\hline 4 & $\begin{array}{c}\text { Soil+ 20\% Steel Slag Type A + } \\
10 \% \text { Bitumen Emulsion }\end{array}$ & 1.661 \\
\hline
\end{tabular}

Following graph shows the variation of Unconfined Compressive Strength of soil with the optimum percentage of steel slag, bitumen emulsion and combination of both.

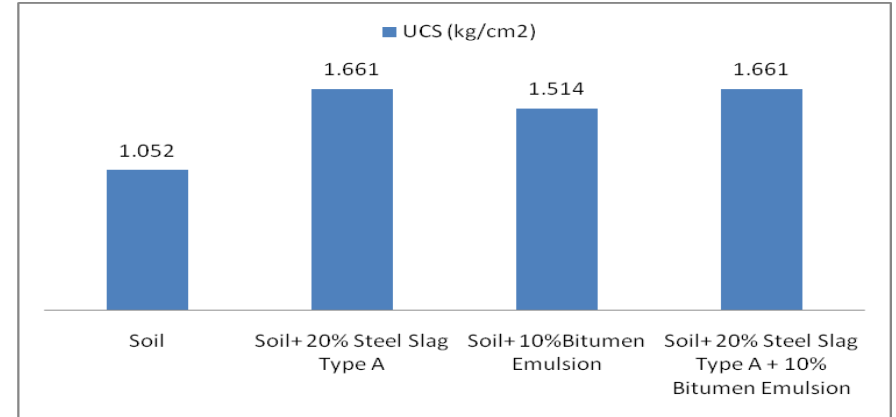

Graph 4 Unconfined Compressive Strength of Soil with Materials

4. Total Thickness of Pavement in $\mathrm{mm}$ with Different Material

The following table shows the thickness of pavement for different combination of percentage of materials with soil.

Table 6 Thickness of Flexible Pavement with Materials

\begin{tabular}{|c|c|c|c|c|c|c|c|}
\hline $\begin{array}{l}\text { Sr. } \\
\text { N } \\
\text { o. }\end{array}$ & $\begin{array}{c}\text { Mater } \\
\text { ial }\end{array}$ & $\begin{array}{c}\text { Desig } \\
\mathrm{n} \\
\text { CBR } \\
(\%)\end{array}$ & $\begin{array}{l}\text { Total } \\
\text { Pave } \\
\text { ment } \\
\text { Thick } \\
\text { ness }\end{array}$ & $\begin{array}{c}\text { Weari } \\
\text { ng } \\
\text { Cours } \\
\mathrm{e}\end{array}$ & $\begin{array}{c}\text { Bind } \\
\text { er } \\
\text { Cour } \\
\text { se }\end{array}$ & $\begin{array}{c}\text { Granula } \\
\text { r Base }\end{array}$ & $\begin{array}{c}\text { Granul } \\
\text { ar Sub- } \\
\text { base }\end{array}$ \\
\hline 1 & Soil & 1.85 & 860 & 40 & 100 & 250 & 470 \\
\hline 2 & $\begin{array}{c}\text { Soil } \\
+20 \% \\
\text { SSA }\end{array}$ & 3.70 & 740 & 40 & 90 & 250 & 360 \\
\hline 3 & $\begin{array}{l}\text { Soil + } \\
25 \% \\
\text { SSB }\end{array}$ & 4.16 & 680 & 40 & 80 & 250 & 310 \\
\hline 4 & $\begin{array}{c}\text { Soil + } \\
10 \% \\
\text { BE }\end{array}$ & 4.47 & 640 & 40 & 80 & 250 & 270 \\
\hline 5 & $\begin{array}{c}\text { Soil + } \\
20 \% \\
\text { SSA + } \\
10 \% \\
\text { BE }\end{array}$ & 5.85 & 620 & 40 & 70 & 250 & 260 \\
\hline 6 & $\begin{array}{c}\text { Soil + } \\
25 \% \\
\text { SSB + } \\
10 \% \\
\text { BE }\end{array}$ & 6.01 & 610 & 40 & 65 & 250 & 255 \\
\hline
\end{tabular}

The following table shows cost of construction for soil and different amount of material used in construction for flexible pavement. 
Table 7 Cost Comparison of Flexible Pavement

\begin{tabular}{|c|c|c|c|}
\hline $\begin{array}{c}\text { Sr. } \\
\text { No. }\end{array}$ & Material & Amount & $\begin{array}{c}\text { Amount } \\
\text { Reduced In } \\
\mathbf{\%}\end{array}$ \\
\hline 1 & Soil & $92,92,185$ & - \\
\hline 2 & Soil +20 \% SSA & $73,12,643$ & 21.30 \\
\hline 3 & Soil + 25 \% SSB & $67,54,680$ & 27.31 \\
\hline 4 & Soil + 10 \% BE & $91,34,810$ & 1.69 \\
\hline 5 & $\begin{array}{c}\text { Soil + 20 \% SSA + } \\
10 \% \text { BE }\end{array}$ & $89,08,968$ & 4.12 \\
\hline
\end{tabular}

The following graph shows cost of construction for soil and different amount of material used in construction for flexible pavement

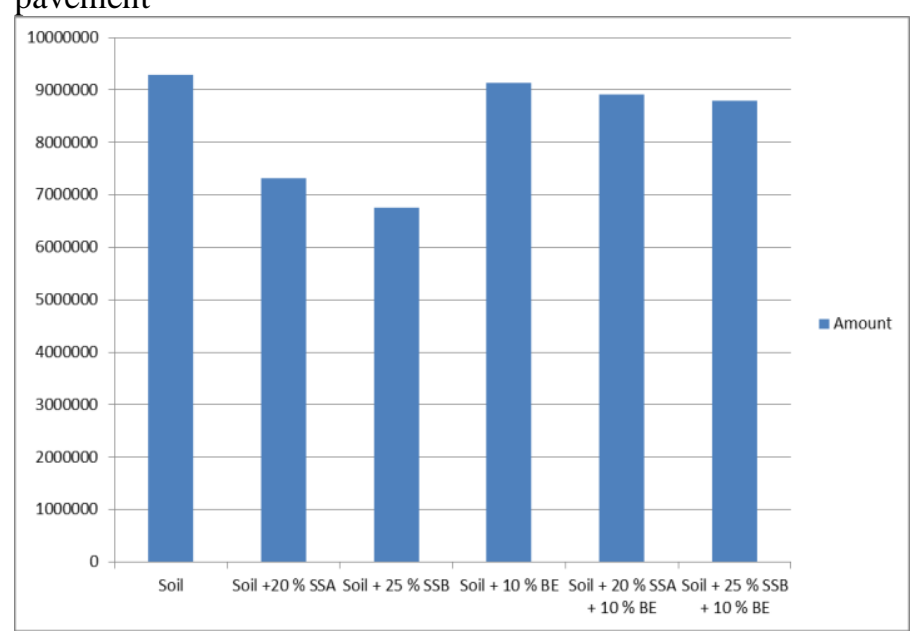

Graph 5 Cost Comparison of Soil with Materials

\section{CONCLUSION}

In this project work, the strength and compaction properties of black cotton soil with steel slag and bitumen emulsion were investigated.

1. From this study, it is clear that there is a considerable improvement in maximum dry density, California Bearing Ratio (CBR) and unconfined compressive strength of black cotton soil due to use of steel slag and bitumen emulsion.

2. It is seen that the best result is obtained when the soil mix with steel slag type B then steel slag type A. The optimum percentage is $25 \%$ \& $20 \%$ for Steel slag Type A\& B respectively.

3. Similarly, the optimum percentage of Bitumen Emulsion is $10 \%$.

4. When the steel slag and bitumen emulsion is mixing together with soil, it gives better result than separately use.

5. The optimum percentage for combination is $20 \%$ steel slag type A and $10 \%$ bitumen emulsion.
Similarly, 25\% steel slag type B and $10 \%$ bitumen emulsion.

6. The unconfined compressive strength of soil is also increase by addition of steel slag and bitumen emulsion at optimum percentage i. e. $20 \%$ steel slag and $10 \%$ bitumen emulsion.

7. By using IRC method, when the pavement is design with origin soil the total thickness of pavement is 860 $\mathrm{mm}$ where as by using stabilized soil the total thickness of pavement is $610 \mathrm{~mm}$.

8. Hence, the reduction of total thickness is $250 \mathrm{~mm}$. therefore cost of material and cost of labours are minimized and directly cost of construction is reduced.

9. The cost of construction of $1 \mathrm{~km}$ road by using stabilized soil the cost is reduced from $5 \%$ to $27 \%$ with variation of steel slag and bitumen emulsion.

10. Also we use waste material as a construction material and save the natural material which used in normal construction of road.

11. Steel slag and bitumen emulsion is recommended for use as a low-cost stabilizer, of local soils with similar engineering properties as that used in this study, for subgrade improvement or constructing a subgrade capping layer during road construction.

\section{Scope for Further Studies}

We know a major problem associated with socio-economic development of a country is waste disposal. Safer disposal of Industrial waste has become a challenging job. Improving properties of soil become an important matter today. There are many alternatives available in doing the same. Here are some suggestions made for further studies using steel slag.

1. Steel Slag size and percentage can be use different.

2. Similar study can be made at different moisture content.

3. Other type of soil can be used for further studies.

4. Other types of bitumen emulsion and different percentage is also used for further work.

\section{ACKNOWLEDGEMENT}

It was great experience for me to be associated with Dr. S. S. KORANNE Associate Professor in Civil Engineering Department, my project guide during this work. I would like to express our deep gratitude to him for his valuable guidance, encouragement and moral support. Here I take an opportunity to convey my sincere thanks to Head of Department Dr. R. V. SHETKAR to support me.

Finally, I would like to express my deep, incomparable appreciation and gratitude to my family for giving constant spiritual support and encouragement to pursue the higher technical education. 


\section{REFERENCE}

\section{Journal Article}

[1] Langar Shubham, Er Bajaj Mohit, (2018), Enhancement of Shear Strength of Soil Using Bitumen, IJSDR, ISSN: 2455-2631.

[2] Olumide Moses Ogundipe, (2014), Strength And Compaction Characteristics Of Bitumen-Stabilized Granular Soil, International Journal Of Scientific \& Technology Research, ISSN 2277-8616.

[3] DebyLinsha R., PreethyDharanya Y., Vinodhini V., (2016), Performance Evaluation Of Improvement Of Shear Strength Of Soil Using Bitumen Emulsion, International Journal of Civil Engineering and Technology (IJCIET), pp. 156-165.

[4] Shashank V., Mrs. Revathi V. (2017), Application Of Steel Slag As An Effective Construction Material In Pavements, IJARIIE-ISSN(O)-2395-4396.

[5] Chippada Srinivas,(2017), Experimental Investigation on Expansive Soil Stabilization by Using Steel Slag, International Journal of Mechanics and Solids. ISSN 0973-1881, pp. 71-76.

[6] Kumar Saurabh, Ved Parkash, Kumar Vishal (2016), Stabilization of Clayey Soil using Steel Slag, International Journal for Research in Technological Studies, ISSN : 2348-143.

[7] Dr. Patil B. M. (2018), Effect of Steel Slag on CBR Value of Black Cotton Soil, International Research Journal of Engineering and Technology (IRJET), ISSN: 2395-0056.

[8] Verma Satyendra Kumar, (2015), A Laboratory Study On Use Of Bitumen Emulsion In Black Soil, International Research Journal of Engineering and Technology (IRJET), pp.83-89.

[9] Yue Huan, Komsun Siripun, Peerapong Jitsangiam and Hamid Nikraz, (2010), A preliminary study on foamed bitumen stabilisation for Western Australian pavements, Scientific Research and Essays, pp. 3687-3700.

[10] Kumar N. Vijay, (2017), study on strength of Laterite soil using bitumen emulsion and ESP, CSA, International Journal of Current Engineering and Scientific Research (IJCEAR), ISSN (Print): 2393-8374, (Online): 23940697.

[11] Yadu Laxmikant \& Dr. Tripathi R.K., (2013), Stabilization of Soft Soil with Steel Slag, Journal of civil Engineering, pp115-119.

[12] Biradar Kiran B, U. Kumar Arun \& Dr. Satyanarayana P.V., (2014), Influence of steel slag \& fly ash on strength properties of clayey soil: A comparative study, International Journal of Engineering Trends \& Technology (IJETT), pp61-64.
[13] Patil Sandip S., Bachhav S.S., Shirsagar D.Y., (2016), Use of steel slag in construction of flexible pavement, International Journal of Engineering and Innovative Technology (IJEIT), pp.145-152.

[14] IS 2720 (PART 5) 1985 Liquid Limit, Plastic Limit

[15] IS 2720 (PART 7) 1980 Light Compaction

[16] IS: 2720 (Part 16) 1979 CBR Test 